\title{
Green Economy for Degenerative Society
}

\author{
Mohammad Imam Sufiyanto ${ }^{1 *}$, Euis Amilia $^{2}$, Diana Puspitasari ${ }^{3}$, Abditama $^{2}$ \\ Srifitriani $^{4}$, Resista Vikaliana ${ }^{5}$, Lilla Puji Lestari ${ }^{6}$
}

\author{
${ }^{1}$ IAIN Madura, Indonesia \\ ${ }^{2}$ Banten Jaya University Serang, Indonesia \\ ${ }^{3}$ Dian NuswantoroUniversity, Indonesia \\ ${ }^{4}$ Universitas Prof Dr Hazairin SH, Indonesia \\ ${ }^{5}$ Institut Ilmu Sosial dan Manajemen Stiami, Indonesia \\ ${ }^{6}$ University Maarif Hasyim Latif Sidoarjo, Indonesia
}

${ }^{*}$ Corresponding author.Email: bersamabiologi@gmail.com

\begin{abstract}
The green economy will be a determining factor in the challenges of the society era. The development of green economy products is needed in responding to the challenges of the society era. This study aims to determine the challenges and constraints of marketing green economy products that are starting to decline and are needed by degenerative communities as food staples. The research approach with the marketing mix carried out in this study recommends that marketing through digital platforms needs to be done to increase the market share of green economy products. Optimization of this digital marketing program is expected to expand market share and strengthen the positioning of green economy products. Products in the green economy sector are very environmentally friendly, but it is very expensive the development of its products, it is necessary to innovate in the marketing sector, product design, and nutritional content as well as raw materials with minimal use of chemicals, to increase people's purchasing power and become the hope for degenerative communities to consume products in the economic sector green. This research is still far from perfect because it requires innovation in the development of the marketing sector and economic products.
\end{abstract}

Keywords: green economic, degenerative, society

\section{INTRODUCTION}

The green economy is a breakthrough in a society era in which we will face a future food shortage, the pattern of empowerment of the generation of farmers is dwindling, and economic needs are increasing, all while the green revolution has yet to be fully explored, necessitating the development of green economy products. [1]. Because agricultural land will become more scarce in the future and demand for agricultural products will rise, the green economy sector will grow [2]. The development of green economy items in the future is very promising in terms of nutritional content, chemical content analysis, and health, ensuring that nutrition fulfillment, chemical effect reduction, and health are progressively guaranteed as green economy growth accelerates [3].

The increased usage of pollutant derived chemical compounds will alter the macro and micronutrient composition of the soil. There are a variety of green economy products available. The focus of this research is on flours made from various types of plant- based basic resources. Processed items manufactured from flour generated from plants have strong nutritional content and are not excessively contaminated by organic toxins that can poison the human body, so they will bring many benefits to the degenerative population. The degenerative civilization need nutrition, particularly from processed green economy items, which will become the brand in the era of society 5.0 [4].

The green economy development pattern is one in which public and private investments generate income growth and employment by reducing carbon emissions and pollution, increasing energy and resource efficiency, and preventing biodiversity and ecosystem services loss [5]. Green economy policy is a policy concept for transitioning away from the industrial sector, which can pollute the environment. Green economy policy is a global issue that is increasingly being promoted by displaying several products that are inexpensive and havea high selling value to agrarian countries, such as Indonesia, which has a large agrarian sector. and as a foodbarn [6]. 
This study attempts to establish the obstacles andrestrictions of marketing green economy products based on the problem of the degenerative community's need for nutrition and nutrition, especially from processed green economy products. This study is necessary because green economy products will make optimal use of natural resources and address environmental concerns as an economic added benefit [7].

\section{LITERATURE REVIEW}

The globalized economic sector's usage of indicators in economic success has been quite prevalent in this decade. In the majority of countries, the marketing sector also develops illusions about development and has an impact on the release of the environmental sector, fostering issues associated to environmental sustainability for the sake of achieving economic success based solely on GDP growth.

The Green Economy is a system in which economic activities associated to the production, distribution, and use of goods and services that have resulted in a long-term rise in human wellbeing can help a country's economy [8].

Today, the Green Economy concept will be the focus of attention. A new invention at the heart of the global economy will be the alternative global market. The effectiveness of its execution will be determined by an understanding of global climate change and the intensity of ordinary economic operations. With an economic system that adheres to a green economy that is safe and friendly to the environment for the production and consumption of products and services, global climate change will undoubtedly be circular [9]. In terms of consumption, and consumers' sense of what constitutes a solution, consider the use of a low-carbon product [10].

Customers also demand and "push" the corporation to respond to market responses as a producer of goods and services. In Europe, goods that do not harm habitats due to carbon capacity (carbon content) are starting to become a trend for a variety of products (eco-labeling), resulting in more active customers picking several products to consume. Of course, numerous certification permissionprocedures are required in the early phases of a low- carbon green market, which are also addressed in the Independent Third-Party Certification System [11]. The Green Economy's nature allows for a reduction in natural resource consumption. Whatever it is, the Green Economyis dedicated to reducing environmental damage while also enhancing economic performance [12].

The Green Economy concept is seen to be an effective strategy to prevent environmental damage and natural resource waste. Cleaner energy also fosters green growth, which reduces environmental damage by utilizing ecologically friendly renewable energy sources [13].

\section{METHOD}

Methods in the form of the marketing mix, such as promotion, venue, pricing, and goods, can also be utilized to empower green economy commodities in this pattern. So that the general public is aware of is variety of marketing characteristics for green economy items [13]. A marketing mix assists businesses in responding to market demands. This philosophy has long been followed in order to boost the company's financial and managerial success. A marketing mix assists businesses in responding to market demands. This philosophy has long been followed in order to boost the company's financial and managerial success. The goal of this strategy is for customers in the target market to focus on choices and make decisions based on these four factors so that they may deliver valuable reactions and accommodate favorable stimuli. Figure 1 also demonstrates this market strategy.

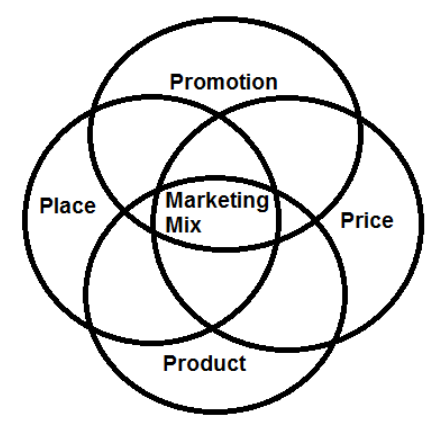

Figure 1. Marketing with the 4P Strategy

\subsection{Product}

Product is a term that describes recalculable commodity commodities and services. Several agreements are in the process of being launched as international products, and they must take into account market brands, benefits, types,stability, consumer safety, design, participation reconstruction, insurance, and services [14].

\subsection{Price}

Pricing at merchants can also be advised, price reductions and market circumstances, increased cash payments and early payments, instant prices, rebates, for a collection of products (bundling), price flexibility, and price discrimination are all examples of quantity decisions [3].

\subsection{Place}

The distribution pattern takes the shape of actions that transport products so that they can reach customers' hands. Distribution channels, marketing regions (inclusive, selective, executive channels), product classification and resources used, supply, central distributors, processed orders, vehicles, and warehousing on various lines are all included in distribution [9]. The marketing product can be used to help determine the marketing location. 


\subsection{Promotion Decision}

Promotion is a powerful language in delivering information to advertise products that are expected to have a positive response from users, and it is a strong language in marketing strategy. The presence of advertising strategies, as well as the opening of bazaars, brochures, community and audience engagements, and market or market interaction budgets [15], are all examples of marketinteraction.

\subsection{Marketing Strategy Limits}

When the bulk of items are released as goods, exposure to marketing strategies is equally critical. Market tactics, including a variety of packaging, procedures, and practices, are also incorporated at this point. While the 4Ps theory applies to market techniques, it is equally applicable to marketing activities. Only a few of the principles can be carried out by those who can produce and have a monopoly, or oligopoly, character and can control the main market, as well as those who are numerous and out of sync for perfectly competitive markets, mainly from the determination of retail traders and selling value in parcels (bundling) [16].

This method can be used in green markets, but it also protects the environment. Product marketing involving horticultural products in order to have an impact on the environment or the growth of a green economy [8]. Green economy marketing is both a managerial and a publicpolicy consideration. In order to promote green economy products, such as the composition of various composite flour products [13], this tactic can be implemented in the industrial section (industrial guide), business factories (annual reporting), facilities (program selection), and labeling.

Green marketing refers to product promotion strategies that prioritize environmental awareness in the areas of structure, local wisdom, and how businesses manufacture things. Amdal, environmental concerns, factory ecology, and environmental preservation are all linked to the promotion of the green economy. Life cycle analysis, raw material effectiveness, raw material flow cycle, and resource eco-efficiency will all be included in corporate social responsibility [15].

\section{RESULT AND DISCUSSION}

\subsection{Green Constitution}

The 1945 Constitution has been revised to provide legal protection for habitats and the environment, however few sectors take this seriously. The facts or statistics regarding Indonesia's control of power are contained in Article $28 \mathrm{H}$ paragraph (1) and Article 33 paragraph (4) of the 1945 Constitution, which is also known as a green constitution. "Everyone has the right to live in bodily and spiritual prosperity, to have a place to dwell, to have a pleasant and healthy environment, and to get health care," says Article $28 \mathrm{H}$ paragraph (1) of the 1945 Constitution.
The green constitution can be explained in terms of environmental power, which is, in turn, linked to Ecocracy. Environmental sovereignty's potential is a welcome addition to sovereignty theory's current gems. In history, mankind has recognized the concepts of divine sovereignty (Theocracy), popular sovereignty (Democracy), and legal sovereignty (Nomocracy)[6].

The Law of the Republic of Indonesia number 32 year 2009 concerning Environmental Management is a reform of the Law of the Republic of Indonesia number 32 year 2009. "Environmental protection and management" is defined in Article 1 as "systematic and integrated actions done to preserve[10]."

Planning, utilization, control, maintenance, supervision, and law enforcement are all part of the environment's function and prevention of pollution and/or environmental damage. The main distinction between Law of the Republic of Indonesia number 32 of 2009 and Law of the Republic of Indonesia number 23 of 1997 is not onlyin terms of monetary fines, but also in terms of imprisonment for environmental law violators. According to Article 65 of the Republic of Indonesia number 32 of 2009 , "everyone has the right to a good and healthy environment as part of their human rights, everyone has the right to environmental education, access to information, access to participation, and access to justice related to the right to a good and healthy environment, everyone has the right to environmental education, access to information, access to participation, and access to justice related to the right to a good and healthy environment "[11] .

It is also stated that everyone has the right to file a complaint if they believe there has been environmental pollution or devastation. Furthermore, Article 66 specifies that anyone who fights for the right to a good and healthy environment is immune from criminal and civil prosecution. This will encourage people to report environmental problems without fear of retaliation. Any person who intentionally exceeds the ambient air quality standard, water quality standard, seawater quality standard, or standard criteria for environmental damage shall be punished with imprisonment for a minimum of 3 (three) years and a maximum of 10 (ten) years, as well as a fine ranging from Rp. 3 billion to Rp. 10 billion (paragraph 1). Jika perbuatan tersebut mengakibatkan orang luka dan/atau bahaya kesehatan manusia, pelanggar dihukum penjara antara 4 hingga 12 tahun dan denda antara Rp. 4 miliar hingga Rp 12 miliar (ayat 2). Pelanggaran UU lingkungan The perpetrator faces a penalty of 4 to 12 years in prison and a fine of $\mathrm{Rp} 4$ billion to $\mathrm{Rp} 12$ billion if the act causes injury or harm to human health (paragraph 2). Environmental law violations that result in significant harm or death can result in a sentence of 5 to 15 years in jail and a fine of Rp. 5 billion to Rp. 15 billion. Violators of environmental quality requirements may be sentenced toone to three years in prison and fined between Rp. 1 billionand Rp. 3 billion (article 99)[12].

If the release of genetically modified items violates this law, they may be punished and 
imprisoned (Article 101). Similarly, processing B3 garbage without a permit (Article102) and creating B3 waste that is not adequately handled can lead to jail time and fines (Article 103). B3 trash disposal without a permission (Article 104) and waste imports from abroad (Articles 104-107) are likewise punishable by imprisonment and fines. Criminal acts with threats of imprisonment and fines include burning land (Article 108), opening a business without an environmental permit (Article 109), drafting an Amdal without a certificate (Article 110), and providing recommendations for an environmental permit without an Amdal by an official (Article 111) [13].

\subsection{Challenges and Opportunities}

Various firms that claim to be environmentally friendly (green campaign) are not operating in a sustainable manner. The advantages cannot be large, and the expenditures are prohibitively high, among other reasons advanced. Greenwashing is a term used to describe initiatives that put profit over environmental protection.

Consumers frequently suspect intensive promotion through various forms of mass media and product labels of just concealing up undesirable aspects while promoting favorable ones. Furthermore, customer understanding regarding the benefits of products on health and environmental preservation is insufficient to some extent [17].

According to the marketing mix, green marketing efforts must still be carried out in order for customers to recognize the product. To expand market share, digital media must be used for marketing. This digital marketing optimization is projected to increase market share and improve the positioning of green economy products. Product design or look must be packaged to make it more appealing in terms of the product marketing mix. Furthermore, consumers must be able to sense the benefits of the added value. Market niches must also be identified in order to increase market share and construct the marketing mix. However, products managed through agreen economy approach are typically more expensive than identical products generated through traditional methods. Green economy products may appeal to upper middleincome populations with a high level of environmental awareness [15].

\subsection{Green Economy Products}

Organic farming is a complete and integrated agricultural system that optimizes health and productivity in the form of nutrients from natural ecosystems while producing sufficient, high-quality, and long-term food and fiber products. Organic agricultural practices include, among other things, not using genetically modified seeds/seeds, not using synthetic chemical pesticides, and controlling weeds, pests, and illnesses mechanically, biologically, or manually. (5) maintaining and improving soil fertility and productivity through the return of agricultural wastes, manure, and natural mineral rocks, as well as growing legumes and crop rotation, and (6) not utilizing growth hormones and synthetic chemicals in animal feed [16]. Organic agricultural practices include, among other things, not using genetically modified seeds/seeds, not using synthetic chemical pesticides, and controlling weeds, pests, and illnesses mechanically, biologically, or manually. (5) maintaining and improving soil fertility and productivity through the return of agricultural wastes, manure, and natural mineral rocks, as well as growing legumes and crop rotation, and (6) not utilizing growth hormones and synthetic chemicals in animal feed [16].

Organic farming has several advantages, including: (i) organic fertilizers can be provided by farmers at relatively low prices by utilizing livestock and agricultural wastes that are owned or obtained from the surrounding area; (ii) organic fertilizers can increase the physical, chemical, and biological fertility of the soil; and (iii) organic fertilizers can reduce reliance on factory-produced inorganic feces [18].

Organic product marketing still faces a number of challenges. Domestic organic agriculture goods have thus far relied solely on customer and producer confidence. Many organic items are sold without having been certified as organic. The product is advertised as organic, but it was made without adhering to established procedures, such as utilizing a combination of organic and organic fertilizers, as well as the usage of pesticides, albeit in small amounts. Farmers who practice organic farming suffer as a result of this [19].

\subsection{Nutritional and Chemical Composition of Various Flour Types as Green Economy Products for Degenerative (Poverty) Communities}

The nutritional and chemical composition of various varieties of flour is offered to give an overview of the green economy required for the creation of green agricultural goods that are both safe and beneficial to degenerative (poor) societies.

Table 1. Chemical Compositions of Banana Flour, Rice, and Potatoes of Different Types (per $1000 \mathrm{~g}$ of ingredients)

\begin{tabular}{|l|l|l|l|}
\hline \multirow{2}{*}{$\begin{array}{c}\text { Measured } \\
\text { Component }\end{array}$} & \multicolumn{3}{|c|}{ Kinds of Flour } \\
\cline { 2 - 4 } & Banana & Rice & $\begin{array}{l}\text { Potat } \\
\text { o }\end{array}$ \\
\hline Water $(\mathrm{g})$ & 3 & 12 & 78 \\
\hline Calories $(\mathrm{kal})$ & 340 & 363 & 82 \\
\hline Protein $(\mathrm{g})$ & 4,4 & 6,7 & 2,0 \\
\hline Fat $(\mathrm{g})$ & 0,8 & 0,4 & 0,1 \\
\hline Carbohydrates $(\mathrm{g})$ & 88,6 & 80,4 & 19 \\
\hline Crude Fiber $(\mathrm{g})$ & 2,0 & 0,3 & 0,4 \\
\hline Ash $(\mathrm{g})$ & 3,2 & 0,5 & 1,1 \\
\hline Vitamins (mg) & 76,92 & 0,17 & 16,23 \\
\hline
\end{tabular}

Source: (J. Dadhawakt, 2019)

Banana flour has a high carbohydrate content, therefore it can be used to make bread, noodles, biscuits, and other baked goods instead of wheat flour. Banana flour, on the other hand, isn't entirely interchangeable. Wheat flour is still required in the 
manufacture of noodles. Because banana flour contains gluten, which results in soft noodles, wheat flour must be substituted to generate processed items that are crunchy and fluffy.

Erny et al (2012) found that several types of goroho banana flour had a high carbohydrate content of 75.18 percent, with fiber as high as 5.12 percent, protein as high as 5.16 percent, fat 0.97 percent, water 11.29 percent, and ash as high as 2.29 percent. Currently, goroho banana is one type of banana variation that has caught the attention of a lot of people. This could be due to various types of research that revealed a lot of antioxidants in the type of flour made from goroho banana. According to Suryanto et al's research, the goroho banana has the ability to act as anantidote to harmful free radicals since it includes numerous phenolic phytochemicals that can operate ashigh antioxidants.

Table 2. Chemical Characteristics of Soybean Dregs Flourfrom Tofu Making Waste

\begin{tabular}{|l|c|c|}
\hline $\begin{array}{l}\text { Chemical } \\
\text { Characteristics }\end{array}$ & $\begin{array}{l}\text { Wet Soybeans } \\
\text { Dregs }\end{array}$ & $\begin{array}{l}\text { Soybean Dregs } \\
\text { Flour }\end{array}$ \\
\hline Water (\%) & 89,88 & 8,25 \\
\hline Protein (\%) & 1,32 & 11,04 \\
\hline Fat (\%) & 2,2 & 19,69 \\
\hline Ash (\%) & 0,32 & 2,83 \\
\hline Carbohydrate (\%) & 6,3 & 51,50 \\
\hline Total Fiber & 5,69 & 47,72 \\
\hline
\end{tabular}

Source : Department of Health, 2020

Soybeans are a high-protein, low-saturated-fat, cholesterol-free source of vegetable protein with a protein concentration of $35-40 \%$. Which is appropriate for green economy products that can be sold. This study also reveals that eating diverse processed soybeans has a protective effect against type 2 diabetes mellitus, because black soybeans include isoflavones and anthocyanin, which is an antioxidant in the form of glibenclamide, in addition to having a low Imono Globulin (GI). In this investigation, increasing the dose of red dragon fruit juice addition and delivery didn't significantly increase the hypoglycemic impact.

Green economy products, such as various types of processed vegetable flour and other green economy products, have interesting chemical and nutritional content to study in the manufacture of greeneconomy products that can be reached by degenerative communities at affordable prices, and high nutritional content and low in chemicals, making it very safe for degenerative communities.

Because degenerative communities are less able to afford expensive processed products, the use of various types of vegetable flour developed from various kinds of plants will have a good health impact, be environmentally friendly, and have a good selling value, the green economy sector will become the main focus in the era of society.

\section{CONCLUSION}

The Green Economy is a chance for economic activities, particularly agricultural products, to become more ecologically friendly and have better chances. The marketing approach employed can be traditional ways that evolve with technological advancements, but products can be packaged more attractively and consumers' perceptions of benefits can be improved. Because societal costs (efforts to safeguard the environment) can also be considered, green economy items are often more expensive. In this instance, the government must be ableto participate in the promotion of a green economy so that consumer and producer awareness grows. To generate a deterrent impact against environmental destroyers, regulations must be strictly enforced. Organic certification is required in order for consumers to trust green economy products. Furthermore, further work is needed to ensure that product certification evaluates not just the manufacturing process but also the content of the products that have been manufactured and marketed. Because green economy implementation is challenging for individual farmers who operate on a small scale, it necessitates collective participation.

\section{ACKNOWLEDGMENTS}

We thank the anonymous reviewers who have provided constructive suggestions for improving this article.

\section{REFERENCES}

[1] M. A. Sutton et al., "Green economy thinking and the control of nitrous oxide emissions," Environ. Dev., vol. 9, no. 1, pp. 76-85, 2014, doi: 10.1016/j.envdev.2013.10.002.

[2] A. Pina, J. Fournier, and O. Le Corre, "ScienceDirect ScienceDirect ScienceDirect Green Economy Innovation Index ( GEII ) - a normative innovation The 15th International Symposium on District Heating and Cooling approach for Germany \& its FEW Nexus Assessing feasibility of Sandra Holger tempera," 2017.

[3] D. Kolcava and T. Bernauer, "Greening the Economy through Voluntary Private Sector Initiatives or Government Regulation? A Public Opinion Perspective," Environ. Sci. Policy, vol. 115, pp. 61-70, 2021, doi: 10.1016/j.envsci.2020.09.013.

[4] V. Grinevich, F. Huber, M. Karataş-Özkan, and Ç. Yavuz, "Green entrepreneurship in the sharing economy: utilising multiplicity of institutional logics," Small Bus. Econ., vol. 52, no. 4, pp. 859876, 2019, doi: 10.1007/s11187-017-9935-x.

[5] H. Schlör, J. F. Hake, and W. Fischer, "Integrated sustainability assessment of climate impact, land, energy and water use in Germany against the 
background of the UN green economy model and Germany's sustainability strategy," Energy Procedia, vol. 61, no. C, pp. 1-4, 2014, doi: 10.1016/j.egypro.2014.11.891.

[6] D. D'Amato and J. Korhonen, "Integrating the green economy, circular economy and bioeconomy in a strategic sustainability framework," Ecol. Econ., vol. 188, no. July, 2021, doi: 10.1016/j.ecolecon.2021.107143.

[7] A. Bogdan et al., "New Holistic Approach of Bioeconomics and Ecoeconomics Theories, Practical Bridging from the Green Economy to Blue Economy, Trough New Integrated and Innovative Paradigm about 'Bio-eco-geoeconomy,", Procedia Econ. Financ., vol. 8, no. 14, pp. 83-90, 2014, doi: 10.1016/s22125671(14)00066-5.

[8] Y. Lebedev, V. Anufriev, T. Lebedeva, A. Kaminov, and A. Yachmenyova, "Professional Training of Future Green Economy Specialists and Strategic Priorities for Sustainable Subsurface Management," Procedia - Soc. Behav. Sci., vol. 214, no. June, pp. 657-666, 2015, doi: 10.1016/j.sbspro.2015.11.664.

[9] O. Pop, G. C. Dina, and C. Martin, "Promoting the corporate social responsibility for a Green Economy and innovative jobs," Procedia - Soc. Behav. Sci., vol. 15, pp. 1020-1023, 2011, doi: 10.1016/j.sbspro.2011.03.232.

[10] A. Gasparatos, C. N. H. Doll, M. Esteban, A. Ahmed, and T. A. Olang, "Renewable energy and biodiversity: Implications for transitioning to a Green Economy," Renew. Sustain. Energy Rev., vol. 70, no. August 2016, pp. 161-184, 2017, doi: 10.1016/j.rser.2016.08.030.

[11] R. Misso, G. P. Cesaretti, N. Marinelli, I. Viola, and I. P. Borrelli, “'Corporate System' and Green Economy in Campania Region: A Collaborative Platform for the Excellences," Procedia Technol., vol. 8, no. Haicta, pp. 104-111, 2013, doi: 10.1016/j.protcy.2013.11.015.

[12] S. N. Agathos, F. Fava, and A. Scoma, "Biotechnology for the bio- and green economy," N. Biotechnol., vol. 30, no. 6, pp. 581-584, 2013, doi: 10.1016/j.nbt.2013.08.009.

[13] F. Caprotti, "Technology in Society De fi ning a new sector in the green economy: Tracking the techno- cultural emergence of the cleantech sector , 1990 e 2010," vol. 46, pp. 80-89, 2016.

[14] L. Fraccascia, I. Giannoccaro, and V. Albino,
"Green product development: What does the country product space imply?," J. Clean. Prod., vol. 170, no. January, pp. 1076-1088, 2018, doi: 10.1016/j.jclepro.2017.09.190.

[15] E. Maria, P. Marina, and G. Pavel, "Global Trends of «Green» Economy Development as a Factor for Improvement of Economical and Social Prosperity," Procedia - Soc. Behav. Sci., vol. 166, pp. 194-198, 2015, doi:

10.1016/j.sbspro.2014.12.509.

[16] P. Mealy and A. Teytelboym, "Economic complexity and the green economy," Res. Policy, no. April, pp. 1-24, 2020, doi: 10.1016/j.respol.2020.103948.

[17] P. Demirel, Q. C. Li, F. Rentocchini, and J. P. Tamvada, "Born to be green: new insights into the economics and management of green entrepreneurship," Small Bus. Econ., vol. 52, no. 4, pp. 759-771, 2019, doi: 10.1007/s11187-0179933-z.

[18] Q. Ye, R. Zhou, M. A. Anwar, A. N. Siddiquei, and F. Asmi, "Entrepreneurs and environmental sustainability in the digital era: Regional and institutional perspectives," Int. J. Environ. Res. Public Health, vol. 17, no. 4, 2020, doi: 10.3390/ijerph17041355.

[19] Z. A. S. Bahlawan, A. Damayanti, Megawati, K. Cahyari, N. Andriani, and R. A. Hapsari, "Study of glucomannan extraction with hydrochloric acid catalyst and alcohol solvent based on porang tuber flour (Amorphophallus oncophyllus)," IOP Conf. Ser. Earth Environ. Sci., vol. 700, no. 1, 2021, doi: 10.1088/1755-1315/700/1/012069. 